\title{
The ecology of plankton in biological oceanography: a tribute to Marta Estrada's task
}

\author{
Jordi Solé ${ }^{1}$, Elisa Berdalet ${ }^{1}$, Laura Arin ${ }^{1}$, Lluïsa $\operatorname{Cros}^{1}$, Maximino Delgado ${ }^{1}$, Akira Kuwata ${ }^{2}$, \\ Clara Llebot ${ }^{3}$, Cèlia Marrasé ${ }^{1}$ \\ ${ }^{1}$ Institute of Marine Sciences, ICM-CSIC. Passeig Marítim de la Barceloneta, 37-49, 08003 Barcelona, Catalonia, Spain. \\ E-mail: jsole@icm.csic.es \\ ${ }^{2}$ Tohokku National Fisheries Research Institute, Japan Fisheries Research and Education Agency, Shinhama-cho 3-27-5, \\ Shiogama, Miyagi, 985-0001, Japan. \\ ${ }^{3}$ College of Oceanic and Atmospheric Sciences, Oregon State University 104 COAS Administration Building Corvallis, \\ OR 97331-5503, USA.
}

\begin{abstract}
Summary: Plankton ecology has been the object of intense research and progress in the last few decades. This has been partly due to technological advances that have facilitated the multidisciplinary and high-resolution sampling of ecosystems and improved experimentation and analytical methodologies, and to sophisticated modelling. In addition, exceptional researchers have had the vision to integrate all these innovative tools to form a solid theoretical background in ecology. Here we provide an overview of the outstanding research work conducted by Professor Marta Estrada and her pioneering contribution to different areas of research in the last four decades. Her research in biological oceanography has mainly focussed on phytoplankton ecology, taxonomy and physiology, the functional structure of plankton communities, and physical and biological interactions in marine ecosystems. She has combined a variety of field and laboratory approaches and methodologies, from microscopy to satellite observations, including in-depth statistical data analysis and modelling. She has been a reference for scientists all over the world. Here, her contributions to plankton ecology are summarized by some of her students and closest collaborators, who had the privilege to share their science and everyday experiences with her.
\end{abstract}

Keywords: phytoplankton ecology; taxonomy; functional structure of plankton communities; physical-biological interactions.

\section{La ecología del plancton en la oceanografía biológica: un homenaje a la labor de Marta Estrada}

Resumen: La ecología del plancton ha experimentado una intensa investigación y progreso en las últimas décadas. Esta se ha debido, en parte, a los avances tecnológicos que han facilitado la toma de muestras multidisciplinar y de alta resolución de los ecosistemas, la mejora de la experimentación y metodologías analíticas y el modelado matemático/numérico. El papel de investigadores excepcionales que han tenido la visión de integrar todas estas herramientas innovadoras a una sólida formación teórica en la ecología ha sido clave en este avance. A continuación hemos elaborado un resumen de la tarea de investigación llevada a cabo por la profesora Marta Estrada y su contribución pionera a diferentes áreas de investigación en las últimas cuatro décadas. Su investigación, en el marco de la oceanografía biológica, se ha centrado principalmente en la ecología del fitoplancton, su taxonomía y fisiología, la estructura funcional de las comunidades de plancton y las interacciones físicas y biológicas en los ecosistemas marinos. Ha combinado una variedad de enfoques y metodologías de campo y de laboratorio, desde observaciones por satélite, hasta el análisis en profundidad de datos estadísticos y el uso del modelado tanto analítico como numérico. La profesora Estrada ha sido una referencia para los científicos alrededor del mundo. Aquí, su contribución a la ecología del plancton la resumen algunos de sus alumnos y colaboradores más cercanos que han tenido el privilegio de compartir ciencia y vivencias con ella.

Palabras clave: ecología del fitoplancton; taxonomía; estructura funcional de las comunidades plantónicas; interacciones física-biología.

Citation/Como citar este artículo: Solé J., Berdalet E., Arin L., Cros L., Delgado M., Kuwata A., Llebot C., Marrasé C. 2016. The ecology of plankton in biological oceanography: a tribute to Marta Estrada's task. Sci. Mar. 80S1: 33-38. doi: http://dx.doi.org/10.3989/scimar.04520.06D

Editor: D. Vaqué.

Received: July 20, 2016. Accepted: July 21, 2016. Published: September 30, 2016.

Copyright: ( 2016 CSIC. This is an open-access article distributed under the terms of the Creative Commons Attribution (CC-by) Spain 3.0 License. 


\section{INTRODUCTION}

Professor Marta Estrada obtained her degree in Biology (1968) and in Medicine (1970) from the University of Barcelona. Her PhD thesis, "Studies on aquatic organism populations in a non-uniform environment" ("Estudios sobre poblaciones de organismos acuáticos en medio no uniforme"), was supervised by Ramon Margalef (1919-2004), the most important Catalan and Spanish ecologist, limnologist and biological oceanographer of the twentieth century (Estrada 2004). Estrada's research, mainly focusing on biological oceanography, and in particular on the ecology of marine phytoplankton, is a direct continuation of some of the scientific lines developed by Margalef.

Marta Estrada has published widely and led many projects. She has conducted field, laboratory and theoretical studies, combining biochemical, taxonomical and modelling tools. She has studied different freshwater ecosystems (lagoons and rivers in the Iberia Peninsula) and marine ecosystems in the Mediterranean (including the adjacent Barcelona coastal zone, the Ebro Delta and its bays, and open sea waters), across the Atlantic, in Arctic and Antarctic waters, in the Equatorial Pacific upwelling, and in the Indo-Pacific Ocean. Direct observation of nature - in particular thousands of microplankton samples-has provided her with a rich, comprehensive vision of ecosystems. She applied her outstanding skills in mathematics and modelling to understand the complexity of the links between organisms and their dynamics related to environmental forcing. Her perspective was multidisciplinary, integrating knowledge on physical, chemical, biological and geological properties of ecosystems. In the laboratory, she addressed microcosm and ecophysiology studies to elucidate the underlying mechanisms that operate at small scale and that can help to understand natural processes. With exceptional knowledge of phytoplankton taxonomy using optical microscopy, she also combined new tools in electron microscopy, flow cytometry and molecular techniques.

This paper aims to give a brief overview of Marta Estrada's career, compiling the personal views of some of her PhD students and closest collaborators as a brief homage to the more than 40 years that she has dedicated to scientific research. Without the aim of being exhaustive, we have divided her work into four main areas.

\section{COMBINING DIFFERENT APPROACHES TO BUILD A RELIABLE CONCEPTUAL FRAME- WORK}

Estrada's high level of curiosity to unravel the enigmas of nature, together with her multidisciplinary skills, enable her to address a wide range of questions using a wide range of approaches. From the very beginning of her career (Estrada 1972, Estrada and Wagensberg 1977), she applied mathematical tools such as time series and multiparametric analyses to quantitatively describe the apparent caprices of phytoplankton temporal and spatial variability. During her career she combined these mathematical tools with experimental studies and fieldwork to address questions such as the importance of water hydrodynamics in phytoplankton composition. She examined the response of natural plankton assemblages to a combination of treatments in several experimental designs. The data obtained experimentally proved that nutrient-high turbulence favours the dominance of diatoms. These studies corroborated the conceptual ecological framework of Margalef's Mandala (Margalef 1978, Margalef et al. 1979), which proposes a systematization of the functional morphology of phytoplankton on the basis of the supply of nutrients and the intensity of turbulence. Furthermore, the experiments pointed out the importance of initial conditions in the phytoplankton response to treatments (Estrada et al. 1987, 1988, Alcaraz et al. 1989). Estrada also inspected this question in the field. Analysing data from three legs of a winter NW Mediterranean survey, she observed that the dominance of diatoms increased as the intensity of stratification decreased (Estrada 1999, Estrada et al. 1999). In numerous field studies, she showed her interest in framing biological variability with physical processes. Here we cite some papers from her inspections in relation to upwelling (Estrada 1974, 1978, 1991), coastal processes (Estrada and Blasco 1979, 1985, Estrada and Marrasé 1987), fronts (Estrada 1991, Estrada and Margalef 1988), stratification (Estrada et al. 1992, Brink et al. 1995), eddy processes (Granata et al. 2004) and other physical processes (Morán et al. 1999, Llebot et al. 2011, Arin et al 2013). She also helped to quantify the importance of plankton activity in biogeochemical fluxes under different conditions of nutrient and light availability. To address these questions she used a variety of approaches, ranging from experimental work (Estrada et al., 2003, Berdalet et al. 1992, 1994) to field work (Estrada 1979, Estrada et al. 1999), and different biogeochemical methodologies: phosphorus nutrient deficient inputs (Berdalet et al. 1996), biochemical relations with primary production (Berdalet et al. 1993b, Latasa et al. 1992, 2005), $\mathrm{CO}_{2}$ links with frontal zones (Delgado and Estrada 1994), relationships of dissolved organic carbon with phytoplankton (Estrada and Morán 1996), DNA relative to biomass (Arin et al. 1999), excess of carbohydrate synthesis (Fraga et al. 1999), variability of photosynthesis parameters (Morán and Estrada 2001) and enzyme kinetics principles (Packard et al. 2004).

\section{STRUCTURE OF PHYTOPLANKTON COMMUNI- TIES RELATED TO ENVIRONMENTAL FORC- INGS. FIELD STUDIES}

Estrada studied the variability of the size structure and taxonomic composition of phytoplankton communities (Delgado et al. 1992, Estrada and Delgado 1990, Estrada et al. 1993) and their link with environmental dynamics (Morán et al. 2001). For instance, in the Mediterranean Sea Arin et al. (2002) showed how the short-term variability of the physico-chemical water conditions modulated the size structure of autotrophic communities. In the western Alboran Sea anticyclonic 
gyre, for several days picoplankton $(<2 \mu \mathrm{m}$ in cell size, including picoeukaryotes and cyanobacteria) was dominant in the oligotrophic area of the centre of the gyre. In contrast, in the high hydrodynamic and eutrophic zone of the edge, the predominant fraction varied from nanoplankton (2-20 $\mu \mathrm{m}$, mainly autotrophic flagellates) to microplankton ( $>20 \mu \mathrm{m}$, mostly diatoms) as a result of an injection of nutrients at the surface from upwelled deep waters. In a long-term variability (Arin et al. 2005) and a highly dynamic Mediterranean ecosystem (the Ebro shelf area), the picoplankton fraction was the main contributor to the autotrophic biomass (in terms of chlorophyll $a$ ) in the three seasons studied (winter, summer and autumn). The nanoplankton community showed the lowest variability among seasons, while microplankton was higher in winter than in the other seasons, supported by the intrusion of nutrients into the photic zone by intense vertical mixing and strong riverine inputs.

Estrada also participated in long-term studies about phytoplankton dynamics in a fixed observatory station in Barcelona harbour. An important finding derived from these studies was that coastal fertilization by offshore waters during atypical weather conditions (cold and dry winters) may be equal to, or more important than, continental fertilization and may introduce organisms typically thriving in open oceanic waters to coastal waters (Arin et al. 2013). In this situation, some of these taxa, in particular the foam-forming Phaeocystis sp., can proliferate, causing a considerable deterioration of coastal water quality (Arin et al. 2014).

Estrada also used multivariate analysis of organism abundances to explore the distribution of phytoplankton assemblages as a function of environmental conditions. A principal component analysis in an upwelling region of NW Africa, for example, showed that species belonging to the same taxonomic groups were strongly associated, reflecting a similar ecological response (Margalef and Estrada 1981). These analyses also contribute to the efforts to quantify the conceptual model of the Margalef Mandala, as noted above.

Principal component analysis was also used in Alfacs Bay (NW Mediterranean) to characterize the variability of the phytoplankton community related to physical and chemical forcings. The analysis revealed that freshwater influence was the main factor affecting the composition of phytoplankton species, and it also identified an assemblage of marine diatoms (in autumn) and a dinoflagellate group (in winter and early spring) as the main contributors to the seasonal variability of the phytoplankton community in the bay (Llebot et al. 2011).

Recently, Estrada led the study (Estrada et al. 2016) on the large-scale distribution patterns of the nano- and microphytoplankton collected from 145 oceanic stations during the Malaspina 2010 Expedition (December 2010-July 2011), which covered 15 biogeographical provinces across the Atlantic, Indian and Pacific Oceans between $35^{\circ} \mathrm{N}$ and $40^{\circ} \mathrm{S}$. In general, the water column was stratified, the surface layers were nutrient-poor, and dinoflagellates, other flagellates and coccolithophores were dominant in the nano- and microplankton community (including microalgae and heterotrophic protists), while the contribution of diatoms was only important in zones with shallow nutriclines such as the equatorial upwelling regions. The most striking composition contrast was found between the phytoplankton communities in the upper layers and those corresponding to the chlorophyll maximum depths, separated by tens of metres in the vertical dimension. In contrast, the structure and composition of phytoplankton communities were comparable over extensive transects of tropical and subtropical regions of the world's oceans. The study also showed differences among the phytoplankton communities in the sampled stations in Atlantic, Indian and Pacific waters due to a combination of ecological and historical factors.

\section{HARMFUL ALGAL BLOOMS: A PARTICULAR CASE OF PHYTOPLANKTON ECOLOGY}

The interest in harmful algal blooms (HABs) started early in Estrada's career, as a particular case of the phytoplankton life-forms selected by low turbulence and high nutrient availability in Margalef's Mandala. While the role of nutrients had been widely recognized as a main driver for plankton dynamics, including $\mathrm{HABs}$, Margalef proposed for the first time the particular role of turbulence. Estrada's studies provided new insights into this role in the particular case of the bloom dynamics of dinoflagellates, a group that includes many species involved in HAB phenomena (Berdalet and Estrada 1993a, 2008, Estrada and Berdalet 1997). At the ecophysiological scale, Estrada hypothesized the direct impact of turbulence on dinoflagellate cells. This group of organisms showed reduced reproduction capacity under water column mixing conditions, while they tended to thrive under water column stability. In the laboratory, it was shown that small-scale turbulence could inhibit dinoflagellate cell division (Berdalet 1992), although the response was species-specific (e.g. Berdalet et al. 2007). Interestingly, benthic dinoflagellates such as the harmful species Ostreopsis cf. ovata and Prorocentrum lima could also exhibit differential responses to turbulence that would explain their temporal succession in the benthic community. Very recently, Estrada has been participating in a project that investigates the ecophysiological dynamics of Ostreopsis blooms on the Catalan coast.

More recently, using multi-species and low dimensionality mathematical models, Estrada improved the understanding of biological phenomena such as trophic and competitive interactions in plankton communities. For instance, predator-prey models and two- or three-equation models (low-dimensional models) were compared with multi-species models such as ERSEM (Baretta et al. 1995). With this approach, trophic relationships such as allelopathy and feeding preferences in the occurrence of plankton blooms and HABs of dinoflagellates were addressed (Solé et al. 2005, 2006a, b). These studies revealed that the toxicity in the interspecies competition models (allelopathy) has an effect only when the bloom has already started but not as a starting mechanism. Moreover, the toxicity affecting 
trophic feeding interactions could be a mechanism that favours toxic species over a competitor with a higher intrinsic growth rate.

Using age-structured matrix population models, Estrada investigated the role of the different forms of phytoplankton life cycle (vegetative cells and cysts) in the occurrence and recurrence of HABs (Estrada et al. 2010). The study revealed that although cysts had a small effect on increasing bloom magnitude for an actively growing population of vegetative cells, cysts could be a safety mechanism for reintroducing the species when the vegetative cell population was driven to extinction by unfavourable environmental conditions.

\section{INSIGHT INTO THE TAXONOMY AND LIFE CYCLE OF COCCOLITHOPHORES AND DIATOMS}

Coccolithophorids are an important phytoplankton functional group characterized by their external covering of calcite scales or coccoliths (e.g. Young et al. 1999). These organisms have very complex haplo-diploid life cycles associated with different morphologies. Cros and Estrada (2013) showed how the alternation of life cycle stages and heteromorphology give coccolithophorids the capacity to exploit different ecological niches in the marine ecosystems. In particular, this capacity is an ecological strategy for surviving under different conditions in Mediterranean waters. In their study, Cros and Estrada found haploid holococcolithophores mainly in more oligotrophic upper layers, while the diploid heterococcolithophores inhabited relatively rich deeper waters.

Furthermore, holococcoliths have a higher $\mathrm{Mg} / \mathrm{Ca}$ ratio than heterococcoliths (Cros et al. 2013), which predicts a lower preservation potential of holococcoliths because high-Mg calcite dissolves faster than low-Mg calcite. These characteristics could have paleoceanographic implications and consequences in relation to ocean warming and the increasing acidification of the world oceans (Gibbs et al. 2016). Estrada's interest in this phytoplankton group helped to show that some holococcolith structures (not present in all holococcoliths) can have the ability to scatter ultraviolet radiation (Quintero-Torres et al. 2006), suggesting a possible strategy of increasing the reflection of UV light away from the cell, thus enhancing the ability of the organism to live higher in the water column. The studies in Mediterranean waters led to the description of a new coccolithophore, Picarola margalefii, dedicated to Ramon Margalef (Cros and Estrada 2004), which is now the symbol of the Margalef Award for Ecology (Fig. 1) established by the Government of Catalonia in 2004 (http://web.gencat.cat/en/generalitat/premis/ premi-ramon-margalef/Guardo/index.html).

Marta Estrada has also shed light on the taxonomy and life cycle of diatoms, which are responsible for $40 \%$ of marine global primary production. They have a characteristic rigid silicified cell wall, with most species going through a cycle of diameter size decline and size restoration (usually by auxospore formation). Originally it was thought that this was a consequence

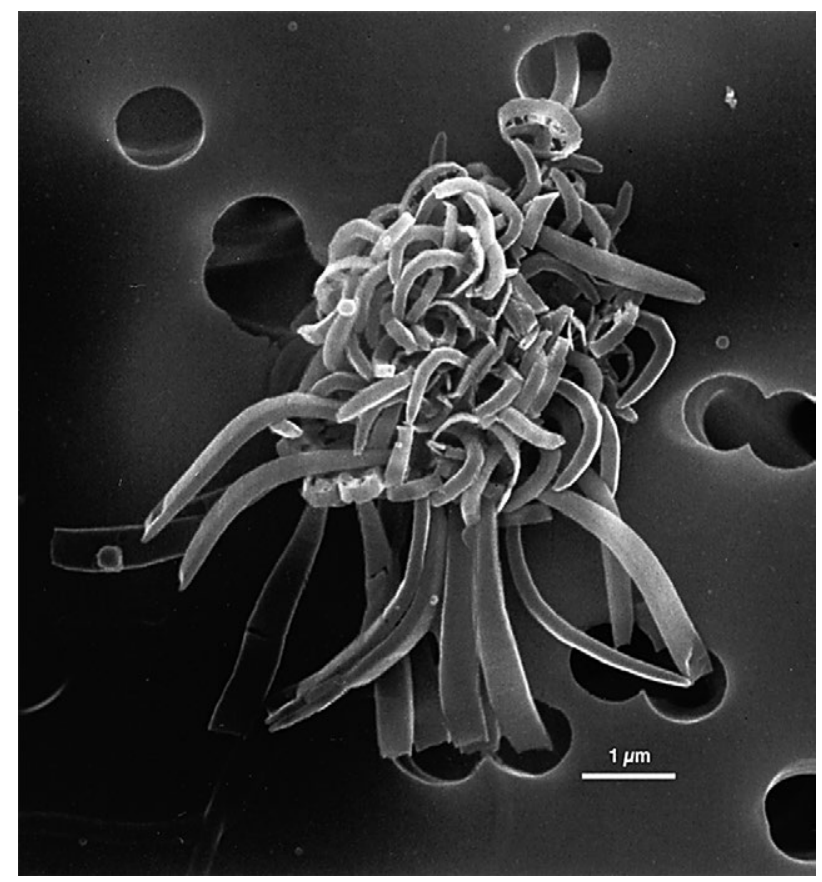

Fig. 1. - The new coccolithophorid Picarola margalefii dedicated to Ramon Margalef (Cros and Estrada 2004), symbol of the Margalef Award for Ecology established by the Government of Catalonia in 2004.

of having a rigid cell wall, but we now know that it is actually related to a sophisticated clocking mechanism for timing the length of their life cycles over periods longer than a year. In the case of one of the smallest diatoms, Minidiscus comicus, which is near the theoretical minimum volume for eukaryote cells, the question was whether they could still use this mechanism. Estrada contributed to the study by Jewson et al. (2016), which shows how M. comicus has adapted to the decline in diameter by changing its cell shape (at division) from discoid to spherical, thus maintaining its cell volume. This finding demonstrates the remarkable adaptability of diatoms in this case, enabling them to colonize and survive in an often overlooked habitat, oceanic nanoplankton.

\section{HAPPY YEARS WITH PHYTOPLANKTON ECOL-} OGY AND MARTA ESTRADA

The authors of this article have spent many years with Marta Estrada, who has been for all of us "our Marta". We have shared 10 to 35 years of our lives with Marta and with phytoplankton... We have learnt about phytoplankton ecology working at sea, calm and rough, either close to our home in the Mediterranean or very far away.

In addition to serious and strict science, we have also shared our personal lives with someone who is extraordinary, generous, hardworking and wise.

... Someone who knows that high pressure and temperature make the most beautiful gems, so effort and perseverance give the best result...

... Someone who has a refined sense of humour to make us understand that humans are like phytoplankton cells, some (almost) naked and fragile, while others 
are nicely and sophisticatedly dressed or armoured: diatoms on glasshouses of silica, coccolithophores with strong walls of calcium carbonate, dinoflagellates wearing fancy cellulose plates, soft flagellates like sweet jelly candies...

... Someone who can always find some funding to pay for the most important necessities of life...

... Someone who always differentiates "maybe" from the "definitely" in a simple way...

... Someone who will turn the puzzled ideas of her students and contributors into a coherent story...

... Someone who will respect opinions and diversity among humans, as a common component of natural selection...

... Someone who believes that observing nature through the microscope is a mirror of humanity and a fantastic road to happiness.

For all of this, thank you Marta!

We are your children forever.

\section{ACKNOWLEDGEMENTS}

This paper was supported by the MINECO-funded project OstreoRisk (CTM2014-53818-R).

\section{REFERENCES}

Alcaraz M., Estrada M., Marrasé C. 1989. Interaction between turbulence and zooplankton in laboratory microcosms. Proc. 21st. E.M.B.S. Gdansk. pp. 191-204

Arin L., Berdalet E., Marrasé C., et al. 1999. Particulate DNA and protein relative to microorganism biomass and detritus in the Catalano-Balearic Sea (NW Mediterranean) during stratification. J Plankton Res. 21: 1299-1316. http://dx.doi.org/10.1093/plankt/21.7.1299

Arin L., Moran X.A., Estrada M. 2002. Phytoplankton size distribution and growth rates in the Alboran Sea (SW Mediterranean): short term variability related to mesoscale hydrodynamics. J. Plankton Res. 24: 1019-1033. http://dx.doi.org/10.1093/plankt/24.10.1019

Arin L., Estrada M., Salat J., et al. 2005. Spatio-temporal variability of size fractionated phytoplankton on the Shelf adjacent to the Ebro river (NW Mediterranean). Cont. Shelf Res. 25: 1081-1095. http://dx.doi.org/10.1016/j.csr.2004.12.011

Arin L., Guillén J., Segura-Noguera M., et al. 2013. Open sea hydrographic forcing of nutrient and phytoplankton dynamics in a Mediterranean coastal ecosystem. Estuar. Coast. Shelf Sci. 133: 116-128. http://dx.doi.org/10.1016/j.ecss.2013.08.018

Arin L., Almeda R., Sampedro N., et al. 2014. Foam events due to a Phaeocystis sp. bloom along the Catalan Coast (NW Mediterranean). Harmful Algae News 48: 14-15.

Baretta J.W., Ebenhöh W., Ruardij P. 1995. The European regional seas ecosystem model: a complex marine ecosystem model. Nether. J. Sea Res. 33: 233-246. http://dx.doi.org/10.1016/0077-7579(95)90047-0

Berdalet E. 1992. Effects of turbulence on the marine dinoflagellate Gymnodinium nelsonii. J. Phycol. 28: 267-272. http://dx.doi.org/10.1111/j.0022-3646.1992.00267.x

Berdalet E., Estrada M. 1993a. Effects of turbulence on several phytoplankton species. In: Smayda T., Shimizu Y. (eds), Toxic Phytoplankton Blooms in the Sea. 5th International Conference on Toxic Marine Phytoplankton, Rhode Island. USA. Book series: Developments in Marine Biology, 3: 737-740. Elsevier Science Publishers B.V. ISBN 0-444-89719-4

Berdalet E., Estrada M. 1993b. Relationships between nucleic acid concentrations and primary production in the Catalan Sea (Northwestern Mediterranean). Mar. Biol. 117: 163-170. http://dx.doi.org/10.1007/BF00346439

Berdalet E., Estrada M. 2008. Modulación de la dinámica de HABs por la turbulencia de pequeña escala. In: Gilabert J. (ed.),
Avances y Tendencias en Fitoplancton Tóxico y Biotoxinas. Actas de la IX Reunión Ibérica sobre Fitoplancton Tóxico y Biotoxinas, Cartagena, 7 al 10 de mayo de 2007, pp. 1-12.

Berdalet E., Latasa M., Estrada M. 1992. Variations in biochemical parameters of Heterocapsa sp. and Olisthodiscus luteus grown on a 12:12 h light:dark cycles. I. Cell cycle and nucleic acid composition. Hydrobiologia 238: 139-147. http://dx.doi.org/10.1007/BF00048782

Berdalet E., Latasa M., Estrada M. 1994. Effects of nitrogen and phosphorus starvation on nucleic acid and protein content of Heterocapsa sp. J. Plankton Res. 16: 303-316. http://dx.doi.org/10.1093/plankt/16.4.303

Berdalet E., Marrasé C., Estrada M., et al. 1996. Microbial community responses to Nitrogen- and Phosphorus-deficient nutrient inputs: microplankton dynamics and biochemical characterization. J. Plankton Res. 18: 1627-1641. http://dx.doi.org/10.1093/plankt/18.9.1627

Berdalet E., Peters F., Koumandou L., et al. 2007. Species-specific physiological response of dinoflagellates to quantified smallscale turbulence. J. Phycol. 43: 965-977. http://dx.doi.org/10.1111/j.1529-8817.2007.00392.x

Brink K.H., Abrantes F.F.G., Bernal P.A., et al. 1995. How do coastal upwelling systems operate as integrated physical, chemical and biological systems and influence the geological record? The role of physical processes in defining the spatial structures of biological and chemical variables. In: Summerhayes C.P., Emeis K.-C., Angel M.V., et al. (eds). Upwelling in the ocean: modern processes and ancient records. John Wiley and Sons Ltd., Chichester, pp. 103-124.

Cros L., Estrada M. 2004. Picarola margalefii, gen. et sp. nov., a new planktonic coccolithophore from NW Mediterranean waters. In: Ros J.D., Packard T.T., Gili J.M., et al. (eds). Biological Oceanography at the turn of the Millenium. Sci. Mar. 68(Suppl. 1): 243-248

Cros L. Estrada M. 2013. Holo-heterococcolithophore life cycles: ecological implications. Mar. Ecol. Prog. Ser. 492: 57-68. http://dx.doi.org/10.3354/meps10473

Cros L. Fortuño J.M., Estrada M. 2013. Elemental composition of coccoliths. $\mathrm{Mg} / \mathrm{Ca}$ relationships. Sci. Mar. 77S1: 63-67. http://dx.doi.org/10.3989/scimar.03727.27E

Delgado O., Estrada M. 1994. $\mathrm{CO}_{2}$ system in a Mediterranean frontal zone. Sci. Mar. 58: 237-250.

Delgado M., Latasa M., Estrada M. 1992. Variability in the sizefractionated distribution of phytoplankton across the Catalan Front of the Northwestern Mediterranean. J. Plankton Res. 14: 753-771. http://dx.doi.org/10.1093/plankt/14.5.753

Estrada, M. 1972. Analyse en composantes principales de données de phytoplancton de la zone côtière du Sud de l'Ebre. Inv. Pesq. 36: 109-118.

Estrada M. 1974. Photosynthetic pigments and productivity in the upwelling region of NW Africa. Tethys 6: 247-260.

Estrada M. 1978. Mesoscale heterogeneities of the phytoplankton distribution in the Upwelling Region of NW Africa. In: Boje R., Tomczak M. (eds), Upwelling Ecosystems. Springer Verlag, Berlin, pp. 15-23. http://dx.doi.org/10.1007/978-3-642-66985-9 3

Estrada M. 1979. Distribución de las reductasas de nitrato en la región de afloramiento del noroeste de Africa. Noviembre 1975. Resultados Expediciones Científicas B/O Cornide 8: 153-159.

Estrada M. 1991. Phytoplankton assemblages across a NW Mediterranean front: Changes from winter mixing to spring stratification. In: Ros J.D., Prat N. (eds), Homage to Ramon Margalef or Why there is such pleasure in studying nature. Oecologia Aquatica 10: 157-185

Estrada M. 1999. Hidrodinàmica i fitoplàncton en el mar Català. Memorias de la Real Academia de Ciencias y Artes de Barcelona 961: 187-247.

Estrada M. 2004. In memoriam Ramon Margalef. Mar. Ecol. Prog. Ser. 276: 1 . http://dx.doi.org/10.3354/meps276001

Estrada M., Blasco D. 1979. Two phases of the phytoplankton community in the Baja California upwelling. Limnol. Oceanogr. 24: 1065-1080.

http://dx.doi.org/10.4319/1o.1979.24.6.1065

Estrada M., Blasco D. 1985. Phytoplankton assemblages in coastal upwelling areas. In: Bas C., Margalef M., Rubiés P. (eds). Simposio Internacional sobre áreas de afloramiento más importantes del Oeste Africano. Barcelona. C.S.I.C., pp. 379-402.

Estrada M., Berdalet E. 1997. Phytoplankton in a turbulent world. 
In: Marrasé C., Saiz E., Redondo J.M. (eds). Lectures on plankton and turbulence. Sci. Mar. 61(Suppl. 1): 125-140.

Estrada M., Delgado M. 1990. Summer phytoplankton distributions in the Weddell Sea. Polar Biol. 10: 441-449. http://dx.doi.org/10.1007/BF00233692

Estrada M., Margalef R. 1988. Supply of nutrients to the Mediterranean photic zone across a persistent front. Oceanol. Acta 1: 133-142.

Estrada M., Marrasé C. 1987. Phytoplankton biomass and productivity off the Namibian coast. S African J. Mar. Sci. 5: 347-356. http://dx.doi.org/10.2989/025776187784522234

Estrada M., Wagensberg M. 1977. Spectral analysis of spatial series of oceanographic parameters (fluorescence, temperature, concentrations of nitrate + nitrite). J. Exp. Mar. Ecol. Biol. 30: 147-164. http://dx.doi.org/10.1016/0022-0981(77)90009-0

Estrada M., Morán J.A.G. 1996. Determination of dissolved organic carbon release by phytoplankton in natural water samples. In: Baeyens J., Dehairs F., Goeyens L. (eds), Integrated marine system analysis. ENIMSA, Vrije Universiteit Brussel, Brusels, Belgium, pp. 58-67.

Estrada M., Alcaraz M., Marrasé C. 1987. Effects of turbulence on the composition of phytoplankton assemblages in marine microcosms. Mar. Ecol. Prog. Ser. 38: 267-281 http://dx.doi.org/10.3354/meps038267

Estrada M., Marrasé C., M. 1988. Phytoplankton response to intermittent stirring and nutrient addition in marine microcosms. Mar. Ecol. Prog. Ser. 48: 225-234. http://dx.doi.org/10.3354/meps048225

Estrada M., Martínez R., Mathot S. 1992. Respiratory electron transport activity in plankton of the Weddell and Scotia Seas during late spring- early summer: relationships with other biological parameters. Polar Biol. 12: 35-42. http://dx.doi.org/10.1007/BF00239963

Estrada M., Marrasé C., Latasa M., et al. 1993. Variability of deep chlorophyll maximum characteristics in the Northwestern Mediterranean. Mar. Ecol. Prog. Ser. 92: 289-300. http://dx.doi.org/10.3354/meps092289

Estrada M., Varela R.A., Sala, J., et al. 1999. Spatio-temporal variability of the winter phytoplankton distribution across the Catalan and North Balearic fronts (NW Mediterranean). J. Plankton Res. 21: 1-20. http://dx.doi.org/10.1093/plankt/21.1.1

Estrada M., Berdalet E., Vila M., et al. 2003. Effects of pulsed nutrient enrichment on enclosed phytoplankton: ecophysiological and successional responses. Aquat. Microb. Ecol. 32: 61-71. http://dx.doi.org/10.3354/ame032061

Estrada M., Solé J., Anglès S., et al. 2010. The role of resting cysts in Alexandrium minutum population dynamics. Deep-Sea Res. II 57: 308-321. http://dx.doi.org/10.1016/j.dsr2.2009.09.007

Estrada M., Delgado M., Blasco D., et al. 2016. Phytoplankton across tropical and subtropical regions of the Atlantic, Indian and Pacific oceans. PLoS One 11(3): e0151699. http://dx.doi.org/10.1371/journal.pone.0151699

Fraga F., Ríos A. F., Estrada M., et al. 1999. Effect of upwelling pulses on excess carbohydrate synthesis as deduced from nutrient, carbon dioxide and oxygen profiles. Mar. Ecol. Prog. Ser. 189: $65-75$. http://dx.doi.org/10.3354/meps189065

Gibbs S.J., Bown P.R., Ridgwell A., et al. 2016. Ocean warming, not acidification, controlled coccolithophore response during past greenhouse climate change. Geology 24: 59-62. http://dx.doi.org/10.1130/G37273.1

Granata T.C., Estrada M., Zika U., et al. 2004. Evidence for enhanced primary production resulting from relative vorticity induced up- welling in the Catalan Current. Sci. Mar. 68S1: 113-119.

Jewson D., Kuwata A., Cros L., et al. 2016. Morphological adaptations to small size in the marine diatom Minidiscus comicus. Sci. Mar. 80S1: 89-96. http://dx.doi.org/10.3989/scimar.04331.06C

Latasa M., Berdalet E., Estrada M. 1992. Variations in biochemical parameters of Heterocapsa sp. and Olisthodiscus luteus grown in 12:12 light:dark cycles. II. Changes in pigment composition. Hydrobiologia 238: 149-157. http://dx.doi.org/10.1007/BF00048783

Latasa M., Morán X.A.G., Scharek R., et al. 2005. Estimating the carbon flux through main phytoplankton groups in the northwestern Mediterranean. Limnol. Oceanogr. 50: 1447-1458. http://dx.doi.org/10.4319/10.2005.50.5.1447

Llebot C., Solé J., Delgado M., et al. 2011. Hydrographical forcing and phytoplankton variability in two semi-enclosed estuarine bays. J. Mar. Sys. 86: 69-86. http://dx.doi.org/10.1016/j.jmarsys.2011.01.004

Margalef R. 1978. Life-forms of phytoplankton as survival alternatives in an unstable environment. Oceanol. Acta 1: 493-509.

Margalef R., Estrada M. 1981. On upwelling, eutrophic lakes, the primitive biosphere and biological membranes. In: Richards F.A. (ed.), Coastal Upwelling, American Geophysical Union, Washington, 522-529. http://dx.doi.org/10.1029/CO001p0522

Margalef R., Estrada M., Blasco D. 1979. Functional morphology of organisms involved in red tides as adapted to decaying turbulence. In: Taylor D.L., Seliger H.H. (eds), Toxic dinoflagellate Blooms. North Holland, Elsevier, pp. 89-94.

Morán X.A.G., Estrada M. 2001. Short-term variability of photosynthetic parameters and particulate and dissolved primary production in the Alboran Sea (SW Mediterranean). Mar. Ecol. Prog. Ser. 212: 53-67. http://dx.doi.org/10.3354/meps212053

Morán X.A.G., Gasol J.M., Arin L., et al. 1999. A comparison between glass fiber and membrane filters for the estimation of phytoplankton POC and DOC production. Mar. Ecol. Prog. Ser. 187: 31-41 http://dx.doi.org/10.3354/meps187031

Morán X-A.G., Taupier-Letage I., Vázquez-Domínguez E., et al. 2001. Physical-biological coupling in the Algerian Basin (SW Mediterranean): Influence of mesoscale instabilities on the biomass and production of phytoplankton and bacterioplankton. Deep-Sea Res. I 48: 405-437. http://dx.doi.org/10.1016/S0967-0637(00)00042-X

Packard T., Blasco D., Estrada M. 2004. Modeling physiological processes in plankton on enzyme kinetic principles. Sci. Mar. 68S1: 49-56.

Quintero-Torres R., Aragón L., Torres M., et al. 2006. Strong farfield coherent scattering of ultraviolet radiation by holococcolithophores. Physical Review E. 74: 032901 http://dx.doi.org/10.1103/PhysRevE.74.03290.

Solé J., Estrada M., García-Ladona E. 2006a. Biological Control of Harmful Algal Blooms: A modelling study. J. Mar. Sys. 61: 165-179. http://dx.doi.org/10.1016/j.jmarsys. 2005.06.004

Solé J., García-Ladona E. Estrada M. 2006b. The role of selective predation in Harmful Algal Blooms. J. Mar. Sys. 62: 46-64. http://dx.doi.org/10.1016/j.jmarsys.2006.04.002

Solé J., García-Ladona E., Ruardij P., et al. 2005. Modelling allelopathy among marine algae. Ecol. Model. 183: 373-384. http://dx.doi.org/10.1016/j.ecolmodel.2004.08.021

Young J.R., Davis S.A., Bown P.R., et al. 1999. Coccolith ultrastructure and biomineralisation. J. Struct. Biol. 126: 195-215. http://dx.doi.org/10.1006/jsbi.1999.4132 